\title{
The Influence of Using Physics Student Worksheets Assisted by Augmented Reality Toward Students' Creative Thinking Ability
}

\author{
Ernita Apriani ${ }^{1, *}$ Heru Kuswanto ${ }^{2}$, Azizah Ainun Nuha ${ }^{1}$ \\ ${ }^{1}$ Master of Physics Education, Faculty of Mathematics and Natural Sciences, Universitas Negeri Yogyakarta, \\ Indonesia \\ ${ }^{2}$ Department of Physics Education, Faculty of Mathematics and Natural Sciences, Universitas Negeri \\ Yogyakarta, Indonesia \\ *Corresponding author. Email: ernitaapriani.2019@student.uny.ac.id
}

\begin{abstract}
This study aims to determine the influence of using augmented reality assisted student worksheets on students' creative thinking abilities. This type of research is pre-experimental research with Intact Group Comparison using the posttest-only control group design. The research population is 121 students and the sample is 50 students. The product used is a student worksheet assisted by augmented reality on the experimental class's optical instrument material. Students' creative thinking abilities were analyzed from the posttest results using test descriptions. Data were analyzed using an independent t-test assisted by SPSS and descriptive statistics. The results showed that the students' creative thinking ability in the experimental class using augmented reality assisted student worksheets is better than the control class in three categories, namely fluency, originality, elaboration. This study shows a significant difference in the average creative thinking ability between students who learn using augmented reality assisted student worksheets and those who do not use augmented reality assisted student worksheets.
\end{abstract}

Keywords: Student worksheets, Augmented reality, Creative thinking ability

\section{INTRODUCTION}

The challenges and demands of the times are getting bigger, especially in terms of education. Education in Indonesia is obliged to follow the demands of that era, one of which is by maximizing skills. In the 21 st century, everyone must have $4 \mathrm{C}$ skills, namely Critic, Creative, Communication, and Collaboration. Creative thinking is also an essential topic in the new educational revolution around the world [1]. Creative thinking is issuing ideas differently or divergent [2]. Creative thinking has four indicators, namely fluency, flexibility, originality, and elaboration [3]. One of the activities that can explore creative thinking by students is using a learning process that focuses on problem-solving. Problem-solving abilities will increase when students give problem-based exercises [4]. Problems given are contextual problems that can be learned by students who think more divergent in solving these problems
[5]. One of the sciences that need problem-solving in physics.

Learning physics in the 21 st century requires students to have more creative thinking [6]. Learning physics will not be separate from solving a problem. In physics learning, learning rarely carries out to encourage students' creative thinking abilities. Creative thinking is a cognitive ability to find various solutions to a problem[7]. Creative thinking rarely does in the learning process. This results in the creative thinking ability of students are low [3]. The indicator of creative thinking that has the lowest percentage is the indicator of authenticity. It is consistent with research [9] shows that students have not been able to think creatively well. Some obstacles can make students not creative such as habits, limited time and energy, the environment, the need for immediate treatment, criticism from others, fear of failure, and satisfaction. The role of educators can prevent it. 
Educators should train every aspect of creative thinking to students, especially developing new thinking and adding useful values to something [10]. When students give a problem, educators can see their creative thinking abilities from the ideas issued as a solution. Students who explore creativity in learning will quickly solve problems in everyday life [11]. The learning model choice influences students' creative thinking ability, such as CPS, PBL, and discovery learning. Project-based learning models can improve students' creative thinking ability [12]. Learning using PjBL-based student worksheets is higher than using cooperative learning models on students' creative thinking ability [13]. In addition to the learning model, the use of technology in learning can also help students solve problems [14]. Current challenges, educators must make fair use of information technology to meet students' needs [15].

Technology can integrate with teaching materials in the learning process. One of the teaching materials that can develop is a student worksheet. Student worksheets are a learning resource that can be developed by educators as facilitators in learning activities. Student worksheets can design according to existing situations and conditions. Student worksheets contain activities or discussions to maximize students' understanding so that learning objectives are more comfortable to achieve [16]. Student worksheets emphasize problem-solving and contextual understanding [17]. Students' creative thinking ability who use student worksheets is more significant than those who do not [12]. Student worksheets will be even more interesting if they integrate with technology.

Teaching materials that integrate with technology make students enthusiastic about participating in learning. One of the uses of technology is augmented reality (AR). It is a technology in three-dimensional (3D) virtual objects that come from real life as markers. There are three main characteristics of AR, namely, the combination of virtual and real, interactive, and three dimensions [18]. Educators can use AR to create authentic, student-centered, and interactive learning[19]. The use of AR in learning can increase learning effectiveness [20]. The use of technology can also improve students' creative thinking ability [21]. In previous research [22], some develop AR-assisted student worksheets on comic material as a medium for training higher-order thinking. The research is only at the development stage, not yet at the implementation stage. AR is more interesting for learning because it visualizes it into a 3D object. Students find it helpful in understanding and analyzing problems [23].
Textbooks as AR markers can use in learning so that students' understanding can be better and more interactive [24] [25]. This paper presents the use of AR-assisted student worksheets on the creative thinking skills of high school students. The augmented reality displayed is a 3D binocular object.

\section{RESEARCH METHOD}

This research is pre-experimental research with the Intact Group Comparison design, as in Table 1. In this research, there is one group used for research but divided into two, namely half the group for the experimental class and half for the control group.

Table 1. Research design

\begin{tabular}{|l|l|l|}
\hline Type Class & Treatment & Posttest \\
\hline Experiment & $\mathrm{X}$ & $\mathrm{O}_{1}$ \\
\hline Control & - & $\mathrm{O}_{2}$ \\
\hline
\end{tabular}

$\mathrm{X}$ is the implementation of LKPD assisted by augmented reality, $\mathrm{O}_{1}$ is the result of the posttest after being treated with the implementation of LKPD assisted by augmented reality, and $\mathrm{O}_{2}$ is the result of the posttest which is not treated with the implementation of LKPD assisted by augmented reality. The experimental class is the class that gets treatment to use augmented reality assisted student worksheets on binocular material. While the control class gets learning with the learning media that teachers usually use, namely PowerPoint.

This research is a type of pre-experimental research with Intact Group Comparison. The location of this research is in SMA Negeri 1 Kalasan. This research conduct in the 2nd semester of the school year on 8 May 2020. The study population consisted of 121 students at SMA N 1 Kalasan and a sample of 50 students. This research conduct in two classes: class XI MIA 1 as the experimental class and class XI MIA 3 as the control class. The research instrument used was valid by expert judgment. The questions used to measure the ability to think creatively in essay questions are four questions with four indicators. Data were analyzed using the normality test, homogeneity test, and independent t-test assisted by SPSS and descriptive statistics. The indicators used to determine the creative thinking abilities of students are shown in Table 2. 
Table 2. The indicators of creative thinking instruments

\begin{tabular}{|c|c|}
\hline $\begin{array}{l}\text { Creative Thinking } \\
\text { Indicators }\end{array}$ & $\begin{array}{l}\text { Exercise } \\
\text { Indicators }\end{array}$ \\
\hline $\begin{array}{l}\text { Fluency: provides ideas } \\
\text { about relevant answers }\end{array}$ & $\begin{array}{l}\text { Students can explain } \\
\text { ideas about relevant } \\
\text { answers through light } \\
\text { formation events on } \\
\text { binoculars }\end{array}$ \\
\hline $\begin{array}{l}\text { Flexibility: create a } \\
\text { variety of ideas from } \\
\text { various points of view }\end{array}$ & $\begin{array}{l}\text { Students can explain } \\
\text { various interpretations / } \\
\text { make various ideas of } \\
\text { various points of view } \\
\text { regarding the binocular } \\
\text { event }\end{array}$ \\
\hline $\begin{array}{l}\text { Originality: giving } \\
\text { answers in their own way }\end{array}$ & $\begin{array}{l}\text { Students can explain } \\
\text { answers about the } \\
\text { events of binoculars } \\
\text { and binoculars in their } \\
\text { own way }\end{array}$ \\
\hline $\begin{array}{l}\text { Elaboration (detail): } \\
\text { developing ideas on a } \\
\text { problem completely, in } \\
\text { detail, and relevant }\end{array}$ & $\begin{array}{l}\text { Students can explain } \\
\text { and compile a complete } \\
\text { and detailed } \\
\text { experimental design of } \\
\text { binoculars }\end{array}$ \\
\hline
\end{tabular}

\section{RESULT AND DISCUSSION}

This study aims to determine the influence of student worksheets assisted by augmented reality on students' creative thinking. This research was carried out during the COVID-19 Pandemic so that learning carries out online / remotely. Learning carries out using the Google Classroom platform, learning using google classroom. Google classroom learning has advantages and disadvantages.

The advantages of using google classrooms are that it saves time and distance, is paperless, increases collaboration between students, and acts as a safe storage area for documents[26]. This study has many obstacles, namely not seeing students' activities directly during learning. Researchers also cannot help directly to students in dealing with difficulties using AR applications. The minimal time made the researcher explain the material, and the discussion was concise. It also affects the process of working on questions whose duration is not long. The process of working on the questions which carry out in each house made it difficult to control, even though there had been suggestions not to look at friends or the internet or other sources. It is consistent with research[27]. There are drawbacks to the use of google classroom, which is less useful for teaching and learning activities. Google classroom is beneficial only for assignment activities. Teaching materials distributed through google classroom. The experimental class gives student worksheet treatment assisted with augmented reality, as in Figure 1. The teaching materials given to the control class were PowerPoint through google classroom, as in Figure 2.

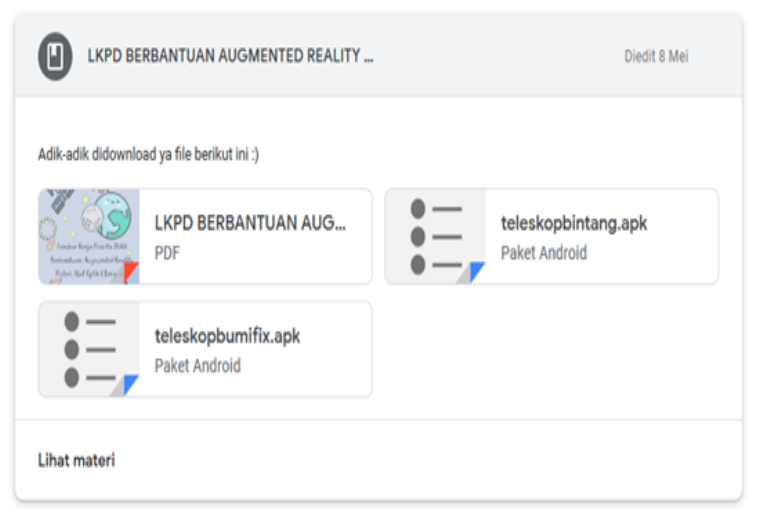

Figure 1. Teaching materials in experimental classes through google classroom

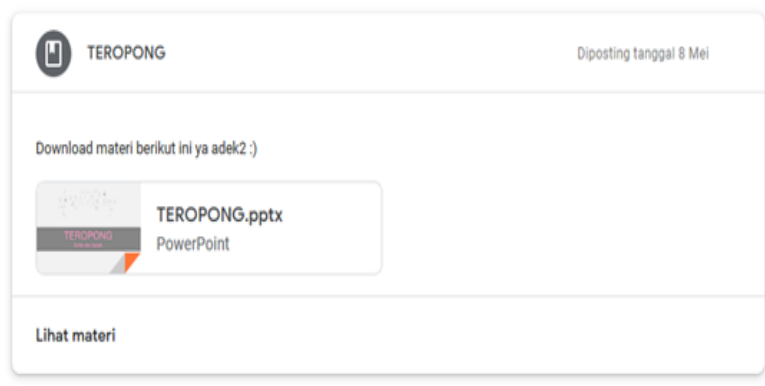

Figure 2. Teaching materials in control classes through google classroom

Students can learn binocular material from student worksheets assisted by augmented reality in the experimental class, as in Figure 3. Making augmented reality provides markers with contrasting colors, making 3-D objects, then making augmented reality using unity. Then scan the marker on the student worksheet using Vuforia, which has previously integrated with augmented reality that has made. Students use two smartphones; one smartphone opens the student worksheet as a marker, and the other smartphone use for scanning using the Vuforia application. 


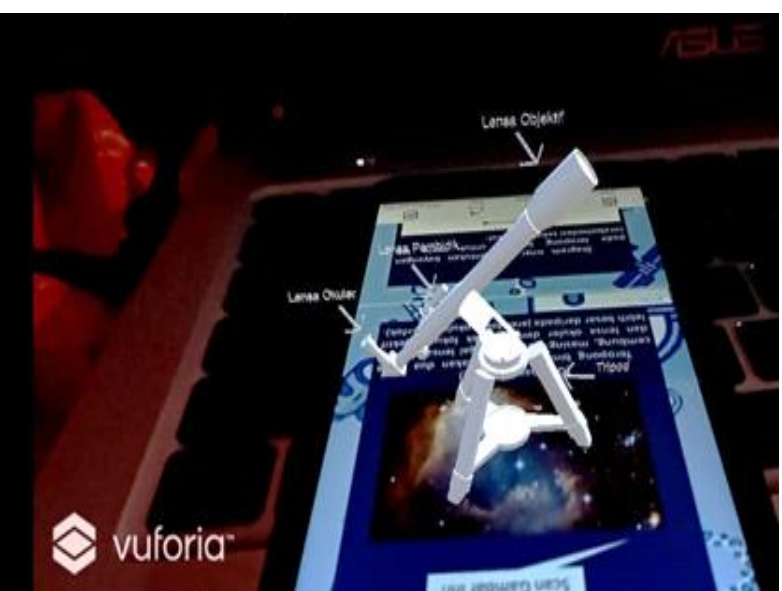

Figure 3. Augmented reality binoculars on student worksheets

In the student worksheet, there is a question that contains one of the indicators of creative thinking, namely elaboration, as shown in Figure 4. In this question, students can answer how to design the earth binoculars according to their respective creativity. Students expect to develop their ideas and ideas in detail and detail according to these questions.

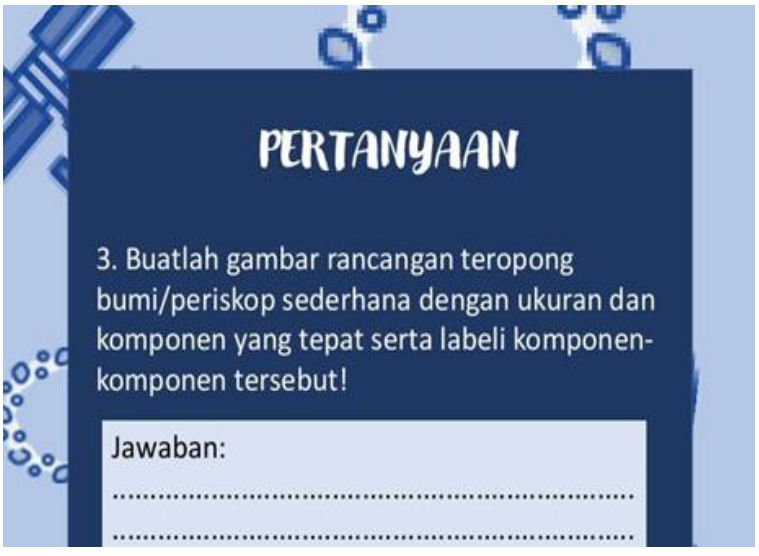

Figure 4. Questions on student worksheets based on indicators of creative thinking

The creative thinking abilities can be measured using a posttest question sheet. The posttest sheet used to determine the creative thinking abilities after using augmented reality assisted student worksheets on binocular material in the experimental class. In the control class, the posttest sheet uses to determine the ability to think creatively after using PowerPoint learning media. Posttest sheet using google form help. Students answer directly on the google form. Figure 5 shows the answer to one of the students in the experimental class.

Meanwhile, Figure 6 shows the answer to one of the students in the control class. The answer is a question that uses an indicator of creative thinking, namely originality. Students can provide their answers. Figures 5 and 6 show that there are differences in students' answers in the experimental class and the control class. They answered according to their ideas. Students who use their ideas and following the theory are students in the experimental class.

\section{Teropong bumi adalah teropong yang digunakan untuk melihat benda-benda jauh di bumi. Supaya bayangan tegak maka teropong bumi dapat dirancang dari teropong bintang dengan menambahkan lensa pembalik. Lensa yang berada di antara lensa objektif dan lensa okuler berfungsi sebagai lensa pembalik, yakni untuk pembalik bayangan yang dibentuk oleh lensa objektif.}

Figure 5. Examples of student answers in the experimental class

mungkin menambahkan beberapa lensa seperti teropong bintang dan mengatur jarak benda terhadap lensa objektif

Figure 6. Examples of student answers in the control class

There are four questions from four indicators. After the student's answers are corrected, a score obtains. With the help of SPSS, these scores analyze. Analysis of the ability to think creatively used the Intact Group Comparison Design design, which then found the average difference value from the independent sample-t-test.

Table 3. Comparison of creative thinking abilities between experiment class and control class

\begin{tabular}{|l|l|l|l|l|}
\hline \multirow{2}{*}{$\begin{array}{c}\text { Class } \\
\text { Type }\end{array}$} & \multirow{3}{*}{ Total } & \multicolumn{3}{|c|}{ Creative Thinking Abilities } \\
Score \\
\cline { 3 - 5 } & & Lowest & Highest & $\begin{array}{c}\text { Avera } \\
\text { ge }\end{array}$ \\
\hline Experiment & 25.0 & 44.0 & 83.0 & 67.3 \\
\hline Control & 25.0 & 36.0 & 77.0 & 59.2 \\
\hline
\end{tabular}

The average value of the creative thinking abilities between the experimental and control classes can see in Table 3. The average value of the experimental class is 67.36, and the control class is 59.24. While the highest score in the experimental class was 83 , and in the control class, it was 77 . The lowest score in the experimental class was 44 , and in the control class, it was 36 . The average, highest, and lowest experimental class scores were higher than in the control class. It shows that augmented reality 
assisted student worksheets to influence creative thinking skills in line with research[28] an increase in the ability to think creatively after being given student worksheets..

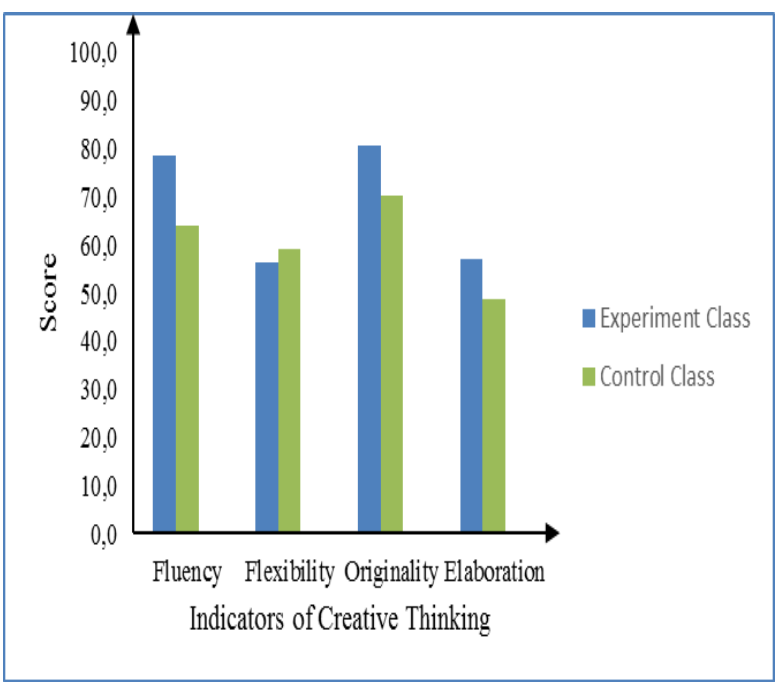

Figure 7. Comparison indicator of creative thinking abilities

There were four measured creative thinking indicators in this study: fluency, flexibility, originality, and elaboration. There are differences in each indicator between the experimental class and the control class. The average score on three indicators, namely fluency, flexibility, and elaboration in the experimental class, is higher than the control class. While on the flexibility indicator, the control class was higher than the experimental class, even though the difference was very little. On the questions of flexibility indicators, students answering questions from these questions do not mention the complete range of ideas or their points of view. Figure 7 shows that the highest indicator is originality, and the lowest is elaboration. According to research [16], Students' creative thinking skills are still low in the elaboration indicator.

Table 4. Normality test results in creative thinking abilities

\begin{tabular}{|l|c|c|c|c|c|c|}
\hline \multirow{2}{*}{} & \multicolumn{3}{|c|}{ Kolmogorov-Smirnova } & \multicolumn{3}{c|}{ Shapiro-Wilk } \\
\cline { 2 - 7 } & Statistics & Df & Sig. & Statistics & df & Sig. \\
\hline Experiment class & 0.14 & 25.00 & $0.20^{*}$ & 0.95 & 25.00 & 0.22 \\
\hline Control Class & 0.16 & 25.00 & 0.08 & 0.94 & 25.00 & 0.14 \\
\hline
\end{tabular}

Table 5. Independent t-test results in creative thinking abilities

\begin{tabular}{|l|c|l|c|c|c|}
\hline Test & T-test & Df & Sig (2-tailed) & Mean diff & Std. Error Diff \\
\hline Posttest Experiment-Control & 2.6 & 48 & 0.012 & 8.120 & 3.110 \\
\hline
\end{tabular}

Before doing the independent t-test, it is necessary to test for normality first, where the homogeneity has a test beforehand. The normality test carries out to determine whether the data collected has a normal distribution or not. Data can be said to be expected if the significance is greater than or equal to 0.05 . Table 4 shows the test results showing that the experimental class's significant value is 0.200 and 0.082 in the control class. The significance value in the two classes is more significant than 0.05 , so the experimental and control class data have a normal distribution. So this research can use the independent t-test.

Table 5 shows the results of the analysis of the independent t-test through SPSS; the significance value is 0.012 , which is smaller than 0.05 . It indicates a significant difference in the ability to think creatively between the experimental class and the control class. The experimental class used an augmented reality assisted student worksheet. It shows that learning using augmented reality assisted student worksheets provides a better chance than everyday learning. It is consistent with research [29], [30] that the use of virtual laboratory assisted student worksheets affects students' conceptual mastery and creative thinking ability.

\section{CONCLUSION}

Students' creative thinking ability in the experimental class using augmented reality assisted three categories, namely fluency, originality, and elaboration. There is a significant difference in students' creative thinking abilities between the experimental class using augmented reality assisted student worksheets and the control class. student worksheets is better than the control class in 


\section{REFERENCES}

[1] P.L. Hsieh, et.al., Physical Activity, Body Mass Index, and Cardiorespiratory Fitness Among School Children in Taiwan: A Cross-Sectional Study, International Journal of Environmental Research and Public Health 11(7) (2014) 72757285 .

DOI: http://doi.org/10.3390/ijerph110707275

[2] E.M. Brodin, Critical and Creative Thinking Nexus: Learning Experiences of Doctoral Students, Studies in Higher Education 41(6) (2016) 971-989. DOI: http://doi.org/10.1080/03075079.2014.943656

[3] D. Athifah, Syafriani, Analysis of students creative thinking ability in physics learning, in: Journal of Physics: Conference Serise, vol. 1185, IOP Publishing, Bristol, 2019, p. 1-8. DOI: $\quad$ http://doi.org/10.1088/1742$\underline{6596 / 1185 / 1 / 012116}$

[4] E.S. Wahyu, Sahyar, E.M. Ginting, The Effect of Problem Based Learning (PBL) Model toward Student's Critical Thinking and Problem Solving Ability in Senior High School, American Journal of Educational Research 5(6) (2017) 633-638. DOI: http://doi.org/10.1088/1742$\underline{6596 / 1006 / 1 / 012016}$

[5] W. Winarti, Contextual Teaching and Learning (CTL) untuk Meningkatkan Kemampuan Berpikir Kreatif Siswa, Jurnal Pendidikan Fisika dan Keilmuan 1(1) (2016) 1-8. DOI: http://doi.org/10.25273/jpfk.v1i1.4

[6] Gunawan, A. Harjono, H. Sahidu, N. Nisrina, Improving students' creativity using cooperative learning with virtual media on static fluida concept, in: Journal of Physics: Conference Serise, vol. 1006, IOP Publishing, Bristol, 2018, p. 1-6. DOI: http://doi.org/10.1088/1742$\underline{6596 / 1006 / 1 / 012016}$

[7] S. Kusumaningrum, D. Djukri, Pengembangan Perangkat Pembelajaran Model Project Based Learning (PjBL) untuk Meningkatkan Keterampilan Proses Sains dan Kreativitas, Jurnal Inovasi Pendidikan IPA 2(2) (2016) 241251.

DOI: https://doi.org/10.21831/jipi.v2i2.5557

[8] A. Santofani, D. Rosana, Pengembangan Tes Kreativitas Pada Pembelajaran Fisika Dengan
Pendekatan Inkuiri pada Materi Teori Kinetik Gas, Jurnal Inovasi Pendidikan IPA 2(2) (2016) 134-144. DOI: https://doi.org/10.21831/jipi.v2i2.6373

[9] S. Utami, B. Usodo, I. Pramudya, Level of students' creative thinking in solid geometry, in: Journal of Physics: Conference Serise, vol. 1227, IOP Publishing, Bristol, 2019, p. 1-9. DOI: $\quad$ http://doi.org/10.1088/1742$\underline{6596 / 1227 / 1 / 012023}$

[10] A. Malik, Y. Nuraeni, A. Samsudin, S. Sutarno, Creative Thinking Skills of Students on Harmonic Vibration Using Model Student Facilitator and Explaining (SFAE), Jurnal Ilmiah Pendidikan Fisika Al-Biruni 8(1) (2019) 77-88.

DOI: https://doi.org/10.24042/jipfalbiruni.v8i1.3056

[11] K.T. Tamimiya, I.G.P. Suryadarma, Potensi Lokal Gunung Ijen untuk Pemahaman Konsep dan Berpikir Kreatif Pengurangan Resiko Bencana, Jurnal Inovasi Pendidikan 5(1) (2019) 117-128.

DOI: http://doi.org/10.21831/jipi.v5i1.25702

[12] H. Habibi, M. Mundilarto, J. Jumadi, S. Gummah, S. Ahzan, D.S.B. Prasetya, Project Brief Effects on Creative Thinking Skills among Low-Ability Pre-Service Physics Teachers, International Journal of Evaluation and Research in Education (IJERE) 9(2) (2020) 415-420.

DOI: http://doi.org/10.11591/ijere.v9i2.20531

[13] S. Mihardi, M.B. Harahap, R.A. Sani, The Effect of Project Based Learning Model with KWL Worksheet on Student Creative Thinking Process in Physics Problems, Journal of Education and Practice 4(25) (2013) 188-200.

[14] H. Jang, J.A. Paulson, Identifying 21st Century STEM Competencies Using Workplace Data, Journal of Science Education and Technology 25(2) (2015) 284-301. DOI: http://doi.org/10.1007/s10956-015-9593-1

[15] M. Ma'ruf, Y. Handayani, D.H. Marisda, R. Riskawati, The needs analysis of basic phy0sics learning devices based on hybrid learning (Eds.), in: Journal of Physics: Conference Series, vol. 1422, IOP Publishing, Bristol, 2020, pp.1-5. DOI: http://doi.org/10.1088/1742$\underline{6596 / 1422 / 1 / 012029}$ 
[16] D. Hernita, D. Djamas, Students analysis for development of student worksheets with metaphorming approach to improve student's creative thinking skills, in: Journal of Physics: Conference Serise, vol. 1185, IOP Publishing, Bristol, 2019, pp. 1-5. DOI: http://doi.org/10.1088/1742$\underline{6596 / 1185 / 1 / 012142}$

[17] K. Podolak, S. Plattsburgh, Interactive Modern Physics Worksheets Methodology and Assessment by Students, European Journal of Physics Education 4(2) (2013) 27-31. DOI: http://doi.org/10.20308/EJPE.03366

[18] F. Saltan, Ö. Arslan, The Use of Augmented Reality in Formal Education: A Scoping Review, Eurasia Journal of Mathematics, Science and Technology Education 13(2) (2017) 503-520.

DOI: http://doi.org/10.12973/eurasia.2017.00628a

[19] M. Wang, et.al., Augmented Reality In Education And Training: Pedagogical Approaches And Illustrative Case Studies, Journal of Ambient Intelligence and Humanized Computing 9(5) (2018) 1391-1402. DOI: http://doi.org/10.1007/s12652-017-0547-8

[20] J.C. Yen, C.H. Tsai, M. Wu, Augmented reality in the higher education: students' science concept learning and academic achievement in astronomy, in: Procedia - Social and Behavioral Sciences, vol. 103, Elsevier, Amsterdam, 2013, p. 165-173. DOI: http://doi.org/10.1016/j.sbspro.2013.10.322

[21] G. Papanastasiou, et.al., Virtual and Augmented Reality Effects on K-12, Higher and Tertiary Education Students' Twenty-First Century Skills, in: Virtual Reality 23(4) (2019) 425-436. DOI: http://doi.org/10.1007/s10055-018-0363-2

[22] F. Bakri, E. Ervina, D. Muliyati, Practice the higher-order thinking skills in optic topic through physics worksheet equipped with augmented reality, in: AIP Conference Proceedings, vol. 2169, AIP Publishing, Maryland, 2019, pp. 1-8. DOI: http://doi.org/10.1063/1.5132647

[23] M. Fidan, M. Tuncel, Integrating Augmented Reality Into Problem Based Learning: The Effects on Learning Achievement and Attitude in Physics Education, Computers and Education $142 \quad$ (2019) $103635 . \quad$ DOI: http://doi.org/10.1016/j.compedu.2019.103635
[24] L. Nadolny, Interactive Print: The Design of Cognitive Tasks in Blended Augmented Reality and Print Documents, British Journal of Educational Technology 48(3) (2017) 814-823. DOI: http://doi.org/10.1111/bjet.12462

[25] C. Lytridis, A. Tsinakos, Evaluation of The ARtutor Augmented Reality Educational Platform in Tertiary Education, Smart Learning Environments 5(1) (2018) 1-15. DOI: http://doi.org/10.1016/j.compedu.2019.103635

[26] I.K. Sudarsana, I.B.M.A. Putra, I.N.T. Astawa, I.W.L. Yogantara, The use of google classroom in the learning process, in: Journal of Physics: Conference Serise, vol. 1175, IOP Publishing, Bristol, 2019, p. 1-5, DOI: http://doi.org/10.1088/1742$\underline{6596 / 1175 / 1 / 012165}$

[27] B.F. Rahmawati, Zidni, Suhupawati, Learning by google classroom in students' perception, in: Journal of Physics: Conference Serise, vol. 1539, IOP Publishing, Bristol, 2020, p. 1-6. DOI: $\quad$ http://doi.org/10.1088/1742$\underline{6596 / 1539 / 1 / 012048}$

[28] J. Sinuraya, I. Wahyuni, D.D. Panggabean, The ICARE practice based on worksheet and physics experimental to improve student creativity, in: Journal of Physics: Conference Serise, vol. 1428, IOP Publishing, Bristol, 2020, pp. 1-6. DOI: http://doi.org/10.1088/1742$\underline{6596 / 1428 / 1 / 012048}$

[29] W. Handayani, W. Setiawan, P. Sinaga, A. Suhandi, Translation among modes of representation by pre-service physics teacher on magnetic force on particle concept Translation among modes of representation by pre-service physics teacher on magnetic force on particle concept, in: Journal of Physics: Conference Serise, vol. 1157, IOP Publishing, Bristol, 2019, pp. 1-7 DOI: http://doi.org/10.1088/1742$\underline{6596 / 1157 / 3 / 032058}$

[30] H. Hermansyah, G. Gunawan, L. Herayanti, Pengaruh Penggunaan Laboratorium Virtual Terhadap Penguasaan Konsep dan Kemampuan Berpikir Kreatif Siswa pada Materi Getaran dan Gelombang, Jurnal Pendidikan Fisika dan Teknologi 1(2) (2017) 97-102. DOI: http://doi.org/10.29303/jpft.v1i2.242 